\title{
The PTPN22 C1858T gene variant is associated with proinsulin in new-onset type 1 diabetes
}

\author{
Lotte B Nielsen ${ }^{1 *}$, Sven Pörksen ${ }^{1}$, Marie Louise M Andersen ${ }^{1}$, Siri Fredheim¹, Jannet Svensson', Philip Hougaard ${ }^{2}$, \\ Maurizio Vanelli ${ }^{3}$, Jan Åman ${ }^{4}$, Henrik B Mortensen ${ }^{1}$, Lars Hansen ${ }^{1}$ and \\ the Hvidoere Study Group on Childhood Diabetes
}

\begin{abstract}
Background: The protein tyrosine phosphatase nonreceptor type 2 (PTPN22) has been established as a type 1 diabetes susceptibility gene. A recent study found the C1858T variant of this gene to be associated with lower residual fasting C-peptide levels and poorer glycemic control in patients with type 1 diabetes. We investigated the association of the C1858T variant with residual beta-cell function (as assessed by stimulated C-peptide, proinsulin and insulin dose-adjusted $\mathrm{HbA}_{1 \mathrm{c}}$ ), glycemic control, daily insulin requirements, diabetic ketoacidosis (DKA) and diabetes-related autoantibodies (IA-2A, GADA, ICA, ZnT8Ab) in children during the first year after diagnosis of type 1 diabetes.
\end{abstract}

Methods: The C1858T variant was genotyped in an international cohort of children ( $n=257$ patients) with newly diagnosed type 1 diabetes during 12 months after onset. We investigated the association of this variant with liquid-meal stimulated beta-cell function (proinsulin and C-peptide) and antibody status 1, 6 and 12 months after onset. In addition $\mathrm{HbA}_{1 c}$ and daily insulin requirements were determined 1, 3, 6, 9 and 12 months after diagnosis. DKA was defined at disease onset.

Results: A repeated measurement model of all time points showed the stimulated proinsulin level is significantly higher $(22 \%, p=0.03)$ for the $T$ allele carriers the first year after onset. We also found a significant positive association between proinsulin and IA levels (est.: 1.12, $\mathrm{p}=0.002$ ), which did not influence the association between PTPN22 and proinsulin (est.: 1.28, $\mathrm{p}=0.03$ ).

Conclusions: The T allele of the C1858T variant is positively associated with proinsulin levels during the first 12 months in newly diagnosed type 1 diabetes children.

\section{Background}

Type 1 diabetes is a T-cell mediated autoimmune disease leading to beta-cell destruction and loss of insulin secretion resulting in severe hyperglycemia. Type 1 diabetes results from a complex interaction between environmental and genetic factors. Several genes have been identified as causative in the development of type 1 diabetes $[1,2]$ and some of these genes as well as other genes are shown to exert an impact on the disease progression from onset in newly diagnosed type 1 diabetes children [3-6]. In a number of studies, the non-synonymous variant, C1858T, of the PTPN22 gene has been associated with

\footnotetext{
* Correspondence: lotbrn01@glo.regionh.dk

'Department of Paediatrics, Glostrup University Hospital, Denmark

Full list of author information is available at the end of the article
}

development of type 1 diabetes as well as other autoimmune diseases [7-11]. Recently, this PTPN22 susceptibility variant was found to be significantly associated to lower fasting C-peptide levels, poorer glycemic control in recent onset type 1 diabetes subjects [6] and to higher GADA in type 1 diabetes patients with long disease duration [12]. The objective of the current longitudinal investigation was therefore to evaluate the impact of PTPN22 on disease progression as assessed by liquid meal-stimulated C-peptide and proinsulin, $\mathrm{HbA}_{1 \mathrm{c}}$, daily insulin dose, insulin dose-adjusted $\mathrm{HbA}_{1 \mathrm{c}}$ (IDAA1C) [13], antibodies to the protein tyrosine phosphatase related IA-2 molecule (IA-2A), islet cell antibodies (ICA), insulin antibodies (IA), glutamic acid decarboxylase antibodies (GADA) and zinc transporter-8 antibodies (ZnT8Ab) in

\section{Biomed Central}

() 2011 Nielsen et al; licensee BioMed Central Ltd. This is an Open Access article distributed under the terms of the Creative Commons Attribution License (http://creativecommons.org/licenses/by/2.0), which permits unrestricted use, distribution, and reproduction in any medium, provided the original work is properly cited. 
the Hvidoere Study Group on Childhood Diabetes (HSG) remission phase cohort [14].

\section{Methods}

The study population representing 15 countries in Europe and Japan was collected through HSG and is described in Mortensen et al 2009 [14]. The cohort included 126 girls and 131 boys, 84\% of the patients were white Caucasian, and age at clinical diagnosis was $9.1 \pm 3.7$ years $\left(\right.$ mean \pm SEM), BMI $16.5 \pm 3.2 \mathrm{~kg} / \mathrm{m}^{2}$, and $\mathrm{HbA}_{1 \mathrm{c}} 11.2 \pm 2.1 \%$ at the time of diagnosis. DKA $\left(\mathrm{HCO}_{3} \leq 15 \mathrm{mmol} / \mathrm{l}\right.$ and/or $\left.\mathrm{pH} \leq 7.30\right)$ was present in $20.7 \%$ of the cases at the time of diagnosis.

Exclusion criteria were: suspected non-type 1 diabetes (type 2 diabetes, maturity-onset diabetes of the young (MODY) or secondary diabetes), decline of enrolment into the study by patients or parents, and patients initially treated outside of the centres for more than 5 days. There were no significant differences with respect to gender distribution, age, anthropometric data, $\mathrm{HbA}_{1 \mathrm{c}}$ at diagnosis, ethnicity or family history of diabetes between patients included and patients not included into the study (data not shown). The diagnosis of type 1 diabetes was according to the World Health Organization criteria. The study was performed according to the criteria of the Helsinki II Declaration and was approved by the local ethic committee in each centre. All patients, their parents or guardians gave informed consent.

In order to estimate the residual beta-cell function (Cpeptide and proinsulin) a liquid-meal Boost ${ }^{\mathrm{TM}}$-test (6 $\mathrm{ml} / \mathrm{kg}$ (max: $360 \mathrm{ml}$, Mead Johnson, Evansville, IN, USA; $237 \mathrm{ml}=8 \mathrm{FL} \mathrm{OZ}$ contains $33 \mathrm{~g}$ carbohydrate, $15 \mathrm{~g}$ protein and $6 \mathrm{~g}$ fat, a total of $240 \mathrm{kcal})$ ) was carried out at 1, 6 and 12 months ( \pm 1 week) after diagnosis in all 257 children with newly diagnosed type 1 diabetes. $\mathrm{HbA}_{1 \mathrm{c}}, \mathrm{IDAA}_{1 \mathrm{c}}$, insulin regimen, HLA typing, antibodies (except ZnT8Ab) and liquid-meal stimulated C-peptide levels were analyzed centrally [14]. Liquidmeal stimulated proinsulin was analysed by a sandwich ELISA assay using two monoclonal antibodies. The assay detects total proinsulin as well as the four metabolites: split(32-33), des(31-329, split(65-66) and des (64-65)-proinsulin. The detection limit is $0.3 \mathrm{pmol} / \mathrm{l}$ and the interassay coefficients of variation are $<8.7 \%$. This assay has no cross reactivity with insulin, C-peptide, IGF-I and IGF-II. ZnT8Ab measurements were done as described in [15]. C1858T genotyping (rs2476601) was done using an in-house KASPar system at KBioscience, UK.

\section{Statistical Analyses}

Stimulated C-peptide (logarithmic) and stimulated proinsulin (logarithmic) at 1, 6, 12 months after diagnosis and $\mathrm{HbA}_{1 \mathrm{c}}$, daily insulin dose and IDAA1C at 1, 3, 6,
9, 12 months after diagnosis were analyzed as dependent variables in two separate multiple regression repeated measurements models with unstructured variance with gender, age, genotype and IA as explanatory factors. The assumption of constant effect of genotype was checked by first allowing for interaction between genotype and disease duration. Results are given as the estimated factor between the T allele carriers (CT and TT) and the $\mathrm{CC}$ genotype. Autoantibodies were examined by the non-parametric Wilcoxon test for single time points. The relationship between IA and proinsulin was tested by multiple regression analysis at each time point with IA (logarithmic), age, gender and stimulated C-peptide (logarithmic) as explanatory factors. There were no statistical differences between the variables according to genotype groups whether the statistical analyses were performed with or without the four Japanese patients. $\mathrm{P}$ values below 0.05 were considered statistically significant.

\section{Results}

The genotype distribution of the PTPN22 C1858T variant among the 257 patients from the HSG [186 CC (73\%), 65 CT (25\%), 6 TT (2\%)] was in Hardy-Weinberg equilibrium. The clinical characteristics according to PTPN22 genotypes are presented in Table 1 . There were no significant genotype differences in clinical and demographic data at disease onset. Excluding the Japanese patients from the following analyses did not change the results.

When analyzing the effect of the PTPN22 gene variant on the residual beta-cell function in a repeated measurement model (including 1, 6 and 12 months) we did not find an effect on the stimulated $\mathrm{C}$-peptide levels the first year after onset (est.: 1.018, $\mathrm{p}=0.88$ ) (Figure 1A).

Table 1 Clinical characteristics at onset in type 1 diabetes subjects according to PTPN22 C1858T genotypes

\begin{tabular}{lccc}
\hline The HSG cohort & \multicolumn{3}{c}{ C1858T genotype } \\
\hline & CC & CT & TT \\
Sex (male/female) & $90 / 96$ & $33 / 32$ & $3 / 3$ \\
Age (yrs) & $9.3 \pm 0.3$ & $8.8 \pm 0.5$ & $6.7 \pm 1.1$ \\
Presences of DKA (+/-) (\%) & $22 / 78$ & $13 / 87$ & $17 / 83$ \\
BMI (kg/m2) & $17.8 \pm 0.2$ & $18.0 \pm 0.4$ & $16.3 \pm 0.6$ \\
HLA risk genes: & & & \\
(Caucasian/Japanese = 253/4) & & & \\
Low (\%) & $52 / 0.8 *$ & 46 & 17 \\
Moderate (\%) & $11 / 0.4 *$ & 14 & 17 \\
High (\%) & $37 / 0.4 *$ & 40 & 67 \\
\hline
\end{tabular}

Data are mean values \pm SEM. HLA DRB1 high risk genotypes: $D R$ 03/04 and $D R$ 04/04; HLA DRB1 moderate risk genotypes: DR 03/03 and DR04/08; all other HLA $D R B 1$ genotypes were considered low risk. The HLA DRB1 genotypes for the 4 Japanese patients were: $D R 01 / 09, D R 04 / 08, D R 09 / 09$ and DR 04/09. These were classified as HLA risk: low, low, moderate and high, respectively* [20]. 


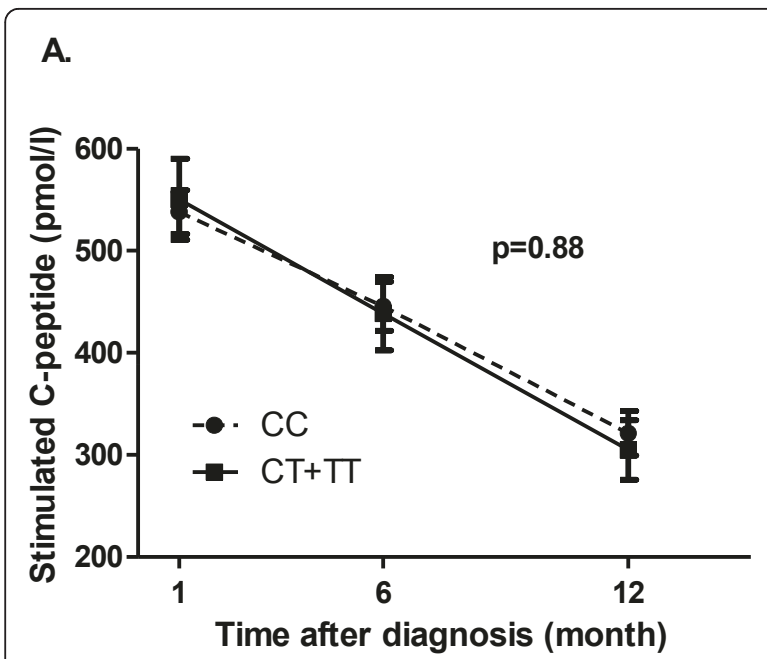

B.

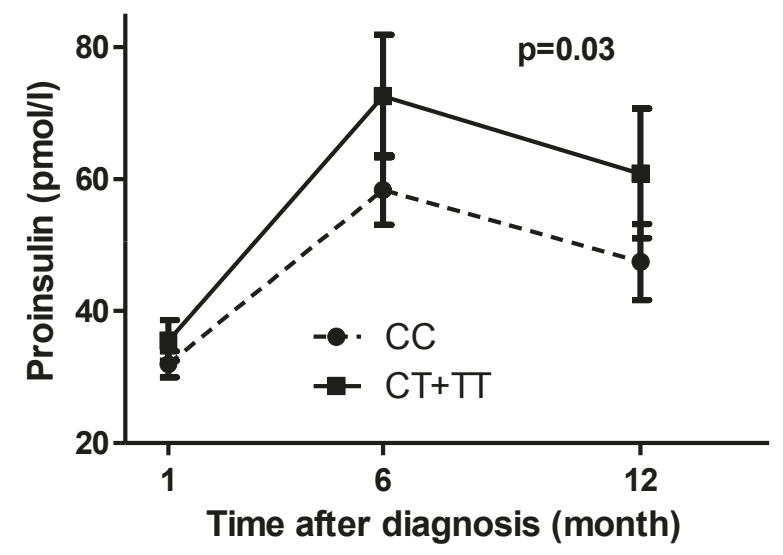

Figure 1 Stimulated C-peptide and proinsulin over time according to PTPN22 genotypes. The association of stimulated Cpeptide (A.) and proinsulin (B.) level 1, 6 and 12 months after disease onset by PTPN22 genotype (homozygous+heterozygous (CT $+T T)(n=71)$ carriers of the variant versus wildtype $(C C)(n=186))$. Mean values $(\mathrm{pmol} / \mathrm{l}) \pm \mathrm{SEM}$.

However, when analyzing the relation between proinsulin and carriers of the C1858T variant we find CT and TT carriers had significantly higher proinsulin (30\%) levels over the 12 month period compared to the CC genotype group (est.: 1.30, $\mathrm{p}=0.03$ ) (Figure $1 \mathrm{~B}$ ). When adjusting for the IA levels in this analysis, we found a significant association between proinsulin and the IA levels (est.: 1.12, $\mathrm{p}=0.002$ ), which, however, did not influence the association between the PTPN22 gene variant and proinsulin (est.: 1.28, $\mathrm{p}=0.03$ ). Furthermore, the CT and TT genotype carriers had a borderline significant higher proinsulin/C-peptide ratio in comparison with the CC genotype carriers (est.: $1.25, \mathrm{p}=0.05$ ).
There were no significant differences in the IDAA1C levels among the PTPN22 carriers, an HbA1c and insulin weighted indirect measure of the residual beta-cell function [13]. Nor did we find any differences between carriers of the PTPN22 variant and the glycemic control (as assessed by $\mathrm{HbA}_{1 \mathrm{c}}$ ) or daily insulin dose.

Finally a significant association was observed between carriers of the CT and TT genotype groups and high IA levels at 12 months after onset (est.: 1.56, p = 0.05) (Figure 2), while there were no significant difference in the IA levels at 1 and 6 months. The prevalence of ZnT8Ab was 68\% 1 month after disease diagnosis (time point nearest to disease onset) for either ZnT8RAb and/ or ZnT8WAb. There was no association between the PTPN22 variant and the other diabetes-related autoantibodies (ICA, IA-2A, GADA and ZnT8Ab), neither close to onset or later during disease progression.

\section{Discussion}

The PTPN22 gene is shown in numerous studies to be associated with the development of type 1 diabetes and other autoimmune diseases. The gene encodes a lymphoid tyrosine phosphatase (LYP) which by dephosphorylation of Src family kinases negatively regulates $\mathrm{T}$ cell receptor (TCR) signalling. The current working hypothesis suggest that the risk carrying allele, T1858, suppresses TCR signalling more efficiently during thymic development resulting in survival of autoreactive $\mathrm{T}$-cells [16].

Bottini $\mathrm{N}$ and co-workers [16] suggested the use of PTPN22 SNPs as a prognostic factor for disease severity and variability in autoimmune diseases, but also requested further studies taking this point under

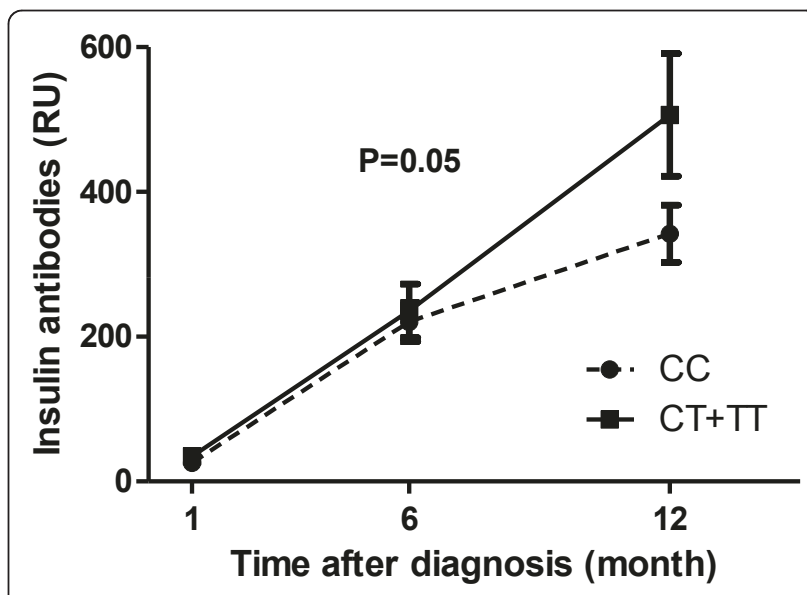

Figure 2 Insulin antibodies over time according to PTPN22 genotypes. Distribution of insulin antibodies (IA) by PTPN22 genotype $((C T+T))(n=71)$ carriers of the variant versus wildtype (CC) $(n=186)) 12$ months after disease onset. Mean values (pmol/l) \pm SEM 
investigation. One such study was recently reported in 120 new onset type 1 diabetes patients (from 5 to 36 years) [6]. The authors found an association between the $\mathrm{T}$ allele of the $\mathrm{C} 1858 \mathrm{~T}$ variant (using a dominant model) and low fasting C-peptide (as a surrogate marker of residual beta-cell mass) and poorer glycemic control $\left(\mathrm{HbA}_{1 \mathrm{c}}\right)$ from onset and during 12 months follow-up. The relationship between carriers of the $\mathrm{T}$ allele and proinsulin was not investigated. The present study, which was conducted in 257 children (from 2 to 16 years) (Table 1 ) with new onset type 1 diabetes, did not find a direct correlation between stimulated C-peptide and the PTPN22 variant (Figure 1A), but suggests an association between carriers of the $\mathrm{T}$ allele and high proinsulin throughout the first year after disease onset (Figure 1B). In accordance with this, an increased proinsulin/C-peptide ratio was evident in the $\mathrm{T}$ allele carriers. Previously, elevated proinsulin and proinsulin/C-peptide ratio was found in non-diabetic first-degree relatives positive for islets autoantibodies to identify individuals with increased risk of developing type 1 diabetes within 5 years [17]. Furthermore, elevated proinsulin levels were found to reflect an impaired beta-cell function in type 2 diabetes patients [18]. Thus, the increased proinsulin level and proinsulin/ $\mathrm{C}$-peptide ratio might either be due to impaired proinsulin processing or increased secretory demand on the betacells resulting from either autoimmunity or hyperglycemia induced residual beta-cell stress.

Circulating IA's are known to change the metabolic clearance rate of proinsulin through proinsulin binding to IgG [19], correspondingly we found a significant positive association between proinsulin and IA levels, irrespective of genotypes (Table 2). This relation did not affect the association between proinsulin and the PTPN22 variant in the statistical analyses. There was a tendency of higher IA levels among the $\mathrm{T}$ allele carriers 12 months after onset (Figure 2), pointing towards a genuine association between IA and the PTPN22 variant, independent of proinsulin. A plausible explanation for these findings could be that PTPN22 $1858 \mathrm{~T}$ is involved in two initially independent processes: first, the severity of autoimmune destruction of beta-cells evidenced by its association with higher proinsulin, this would be in accordance with the data reported by Petrone et al. [6] and second, that PTPN22 1858T is also

Table 2 The relationship between IA and proinsulin

\begin{tabular}{lccc}
\hline & \multicolumn{3}{c}{ Doubling the level of IA } \\
\hline \multirow{3}{*}{ Proinsulin } & $\mathbf{1} \mathbf{m t h}$ & $\mathbf{6}$ mths & $\mathbf{1 2} \mathbf{m t h s}$ \\
& $P=0.002$ & $P=0.007$ & $P<0.00001$ \\
\hline
\end{tabular}

IA levels were associated with proinsulin independent of PTPN22 genotypes as a $100 \%$ increase of the IA corresponded to a significant increase in proinsulin release the first 12 months after disease onset. involved in the antibody response to exogenous insulin treatment. In our case these two processes converge because of the effect that insulin antibodies have on the metabolic clearance rate of proinsulin. Thus, carriers of the PTPN22 1858T allele seem to have both a higher proinsulin and a higher IA level during disease progression despite they are treated with comparable insulin dose as CC carriers.

The discrepancies in significant/non-significant findings on C-peptide levels between this study and the study mentioned above [6] may relate to the use of fasting contra stimulated $\mathrm{C}$-peptide. In the fasting state the differences between the genotype groups and $\mathrm{C}$-peptide are apparent while during liquid-meal stimulated conditions the beta-cells are probably capable of compensating the hyperglycemia but with a rise in proinsulin indicating the stressed residual beta-cell function. Furthermore, the differences in the mean age between the patients from the two studies (14.9 yrs vs $9.1 \mathrm{yrs}$, Petrone et al vs. our study, respectively) might also partly explain the different results. Younger children have less residual beta-cell function as assessed by stimulated C-peptide the first year after diagnosis compared to older age groups [13]. GADA were not related to the PTPN22 variant, supporting previous findings that impact of this gene on the presence of GADA may only be observed in patients with long disease duration (> 10 years) [12].

\section{Conclusion}

Our results align with previous observations that PTPN22 gene variant may be associated with changes in residual beta-cell function and disease pathogenesis during the first year after onset of type 1 diabetes.

\section{List of abbreviations}

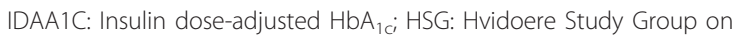
Childhood Diabetes; DR: Danish Remission Phase Study; IA-2A: protein tyrosine phosphatase related IA-2 molecule; GADA: glutamic acid decarboxylase antibodies; IAA: insulin antibodies; ICA: islet cell antibodies, ZnT8Ab: zinc transporter 8 antibodies; SNP: Single nucleotide polymorphism

\section{Acknowledgements}

We thank Novo Nordisk for support throughout this study with special thanks to Drs. Lene Kaa Meier, Stanislav Smirnov and Ralf Ackermann. We are also grateful to Oda Troest (Glostrup University Hospital), Britta Drangsfeldt and Susanne Kjelberg (Steno Diabetes Center) for skilful technical assistance. Members of the Hvidoere Study Group on Childhood Diabetes who have contributed to the Remission Phase Study: Henk-Jan Aanstoot, MD, PhD, Erasmus University Medical Centre, Rotterdam, The Netherlands; Carine de Beaufort, MD, PhD, Clinique Pédiatrique,Luxembourg; Francesco Chiarelli, Professor MD, Clinica Pediatrica, Chieti, Italy; Knut DahlJørgensen, Professor, MD, D M Sc and Hilde Bjørndalen Göthner, MD, Ullevål University Hospital, Department of Paediatrics, Oslo, Norway; Thomas Danne, MD, Charité, Campus Virchow- Klinikum, Berlin, Germany; Patrick Garandeau, MD, Unité D'endocrinologie Diabetologie Infantile, Institut Saint Pierre, France; Stephen A. Greene, MD, University of Dundee, Scotland; Reinhard W. Holl, MD, University of UIm, Germany; Mirjana Kocova, Professor, MD, Pediatric Clinic-Skopje, Republic of Macedonia; Pedro Martul, MD, PhD, 
Endocrinologia Pediatrica Hospital De Cruces, Spain; Nobuo Matsuura, MD, Kitasato University School of Medicine, Japan; Henrik B. Mortensen, MD, DMSc, Department of Pediatrics, Glostrup University Hospital, Denmark; Kenneth J. Robertson, MD, Royal Hospital for Sick Children, Yorkhill, Glasgow, Scotland; Eugen J. Schoenle, MD, University Children's Hospital, Zurich, Switzerland; Peter Swift, MD, Leicester Royal Infirmary Childrens Hospital, Leicester, UK; Rosa Maria Tsou, MD, Paediatric Department Oporto, Portugal; Maurizio Vanelli, MD, Paediatrics, University of Parma, Italy and Jan Åman, MD, PhD, Örebro Medical Centre Hospital, Department of Paediatrics, Sweden

\section{Author details}

'Department of Paediatrics, Glostrup University Hospital, Denmark. ${ }^{2}$ Department of Statistics, University of Southern Denmark. ${ }^{3}$ Department of Paediatrics, University of Parma, Italy. ${ }^{4}$ Department of Paediatrics, Örebro University Hospital, Sweden.

\section{Authors' contributions}

LBN designed the study, contributed to data analysis and wrote the manuscript, SP contributed to data analysis and discussion, MLMA contributed to data analysis, SF contributed to data management, JS contributed to manuscript preparation, PH did the statistical analysis, MV provided the sample and clinical data of study participants, JÅ provided the sample and clinical data of study participants, HBM contributed to data discussion and manuscript preparation, $\mathrm{LH}$ contributed to data analysis, discussion and manuscript preparation. All authors read and approved the manuscript.

\section{Competing interests}

The authors declare that they have no competing interests.

Received: 16 November 2010 Accepted: 23 March 2011

Published: 23 March 2011

\section{References}

1. Wellcome Trust Case Control Consortium: Genome-wide association study of 14,000 cases of seven common diseases and 3,000 shared controls. Nature 2007, 447:661-78.

2. Todd JA, Walker NM, Cooper JD, Smyth DJ, Downes K, Plagnol V, Bailey R, Nejentsev S, Field SF, Payne F, Lowe CE, Szeszko JS, Hafler JP, Zeitels L, Yang JH, Vella A, Nutland S, Stevens HE, Schuilenburg H, Coleman G, Maisuria M, Meadows W, Smink LJ, Healy B, Burren OS, Lam AA, Ovington NR, Allen J, Adlem E, Leung HT, Wallace C, Howson JM, Guja C, Ionescu-Tîrgovişte C, Genetics of Type 1 Diabetes in Finland, Simmonds MJ, Heward JM, Gough SC, Wellcome Trust Case Control Consortium, Dunger DB, Wicker LS, Clayton DG: Robust associations of four new chromosome regions from genome-wide analyses of type 1 diabetes. Nat Genet 2007, 39:857-864.

3. Nielsen LB, Mortensen HB, Chiarelli F, Holl R, Swift P, de Beaufort C, Pociot F, Hougaard P, Gammeltoft S, Knip M, Hansen L, Hvidoere Study Group: Impact of IDDM2 on disease pathogenesis and progression in children with newly diagnosed type 1 diabetes: reduced insulin antibody titres and preserved beta cell function. Diabetologia 2006, 49:71-74.

4. Pörksen $S$, Nielsen LB, Mortensen HB, Danne T, Kocova M, Castaño L, Pociot F, Hougaard P, Ekstrøm CT, Gammeltoft S, Knip M, Hansen L, Hvidøre Study Group on Childhood Diabetes: Variation within the PPARG gene is associated with residual beta-cell function and glycemic control in children and adolescents during the first year of clinical type 1 diabetes. Pediatr Diabetes 2008, 9:297-302.

5. Nielsen LB, Ploug KB, Swift P, Ørskov C, Jansen-Olesen I, Chiarelli F, Holst JJ, Hougaard P, Pörksen S, Holl R, Beaufort C, Gammeltoft S, Rorsman P, Mortensen HB, Hansen L, on behalf of the Hvidøre Study Group: Colocalization of the Kir6.2/SUR1 channel complex with glucagon-like peptide-1 and glucose-dependent insulinotrophic polypeptide expression in human ileal cells and implications for glycaemic control in new onset type 1 diabetes. European Journal of Endocrinology 2007, 156:663-671.
6. Petrone A, Spoletini M, Zampetti S, Capizzi M, Zavarella S, Osborn J, Pozzilli P, Buzzetti R, Immunotherapy Diabetes (IMDIAB) Group: The PTPN22 1858T gene variant in type 1 diabetes is associated with reduced residual beta-cell function and worse metabolic control. Diabetes Care 2008, 31:1214-1218.

7. Bottini N, Musumeci L, Alonso A, Rahmouni S, Nika K, Rostamkhani M, MacMurray J, Meloni GF, Lucarelli P, Pellecchia M, Eisenbarth GS, Comings D, Mustelin T: A functional variant of lymphoid tyrosine phosphatase is associated with type I diabetes. Nat Genet 2004, 36:337-338.

8. Smyth D, Cooper JD, Collins JE, Heward JM, Franklyn JA, Howson JM, Vella A, Nutland S, Rance HE, Maier L, Barratt BJ, Guja C, lonescuTîrgoviste C, Savage DA, Dunger DB, Widmer B, Strachan DP, Ring SM, Walker N, Clayton DG, Twells RC, Gough SC, Todd JA: Replication of an association between the lymphoid tyrosine phosphatase locus (LYP/ PTPN22) with type 1 diabetes, and evidence for its role as a general autoimmunity locus. Diabetes 2004, 53:3020-3023.

9. Begovich AB, Carlton VE, Honigberg LA, Schrodi SJ, Chokkalingam AP, Alexander HC, Ardlie KG, Huang Q, Smith AM, Spoerke JM, Conn MT, Chang M, Chang SY, Saiki RK, Catanese JJ, Leong DU, Garcia VE, McAllister LB, Jeffery DA, Lee AT, Batliwalla F, Remmers E, Criswell LA, Seldin MF, Kastner DL, Amos Cl, Sninsky JJ, Gregersen PK: A missense single-nucleotide polymorphism in a gene encoding a protein tyrosine phosphatase (PTPN22) is associated with rheumatoid arthritis. Am J Hum Genet 2004, 75:330-337.

10. Kyogoku C, Langefeld CD, Ortmann WA, Lee A, Selby S, Carlton VE, Chang M, Ramos P, Baechler EC, Batliwalla FM, Novitzke J, Williams AH, Gillett C, Rodine P, Graham RR, Ardlie KG, Gaffney PM, Moser KL, Petri M, Begovich AB, Gregersen PK, Behrens TW: Genetic association of the R620W polymorphism of protein tyrosine phosphatase PTPN22 with human SLE. Am J Hum Genet 2004, 75:504-507.

11. Velaga MR, Wilson $V$, Jennings CE, Owen CJ, Herington S, Donaldson PT, Ball SG, James RA, Quinton R, Perros P, Pearce SH: The codon 620 tryptophan allele of the lymphoid tyrosine phosphatase (LYP) gene is a major determinant of Graves' disease. J Clin Endocrinol Metab 2004, 89:5862-5865.

12. Chelala C, Duchatelet $S$, Joffret ML, Bergholdt R, Dubois-Laforgue $D$, Ghandil P, Pociot F, Caillat-Zucman S, Timsit J, Julier C: PTPN22 R620W functional variant in type 1 diabetes and autoimmunity related traits. Diabetes 2007, 56:522-526.

13. Mortensen HB, Hougaard P, Swift P, Hansen L, Holl RW, Hoey H, Bjoerndalen H, de Beaufort C, Chiarelli F, Danne T, Schoenle EJ, Aman J, on behalf of the Hvidoere Study Group on Childhood Diabetes: New Definition for the Partial Remission Period in Children and Adolescents with T1D. Diabetes Care 2009, 32:1384-1390.

14. Mortensen HB, Swift PG, Holl RW, Hougaard P, Hansen L, Bjoerndalen H, de Beaufort CE, Knip M, Hvidoere Study Group on Childhood Diabetes: Multinational study in children and adolescents with newly diagnosed type 1 diabetes: association of age, ketoacidosis, HLA status, and autoantibodies on residual beta-cell function and glycemic control 12 months after diagnosis. Pediatr Diabetes 2010, 11:218-226.

15. Vaziri-Sani F, Oak S, Radtke J, Lernmark A, Lynch K, Agardh CD, Cilio CM, Lethagen AL, Ortqvist E, Landin-Olsson M, Törn C, Hampe CS: ZnT8 autoantibody titers in type 1 diabetes patients decline rapidly after clinical onset. Autoimmunity 2010.

16. Bottini N, Vang T, Cucca F, Mustelin T: Role of PTPN22 in type 1 diabetes and other autoimmune diseases. Semin Immunol 2006, 18:207-213.

17. Truyen I, De Pauw P, Jørgensen PN, Van Schravendijk C, Ubani O, Decochez K, Vandemeulebroucke E, Weets I, Mao R, Pipeleers DG, Gorus FK, Belgian Diabetes Registry: Proinsulin levels and the proinsulin:c-peptide ratio complement autoantibody measurement for predicting type 1 diabetes. Diabetologia 2005, 48:2322-9.

18. Røder ME, Porte D Jr, Schwartz RS, Kahn SE: Disproportionately elevated proinsulin levels reflect the degree of impaired B cell secretory capacity in patients with noninsulin-dependent diabetes mellitus. J Clin Endocrinol Metab 1998, 83:604-608.

19. Snorgaard O, Kjems LL, Røder ME, Hartling SG, Dinesen B, Binder C: Proinsulin immunoreactivity in recent-onset IDDM: the significance of insulin antibodies and insulin autoantibodies. Diabetes Care 1996, 19:146-150 
20. Kawasaki E, Matsuura N, Eguchi K: Type 1 diabetes in Japan. Diabetologia 2006, 49:828-36

\section{Pre-publication history}

The pre-publication history for this paper can be accessed here: http://www.biomedcentral.com/1471-2350/12/41/prepub

doi:10.1186/1471-2350-12-41

Cite this article as: Nielsen et al:: The PTPN22 C1858T gene variant is associated with proinsulin in new-onset type 1 diabetes. BMC Medical Genetics 2011 12:41.

Submit your next manuscript to BioMed Central and take full advantage of:

- Convenient online submission

- Thorough peer review

- No space constraints or color figure charges

- Immediate publication on acceptance

- Inclusion in PubMed, CAS, Scopus and Google Scholar

- Research which is freely available for redistribution

Submit your manuscript at www.biomedcentral.com/submit
Ciomed Central 